\title{
The Contribution of Education Expenditure in Saudi Universities to Achieve Economic Development
}

\author{
Hanaa Abdelaty Hasan Esmail ${ }^{1}$ \\ ${ }^{1}$ Thebes Academy, Thebes Higher Institute of Computer and Management Sciences, Cairo, Egypt \\ Correspondence: Hanaa Abdelaty Hasan Esmail, Thebes Academy, Thebes Higher Institute of Computer and \\ Management Sciences, Cairo, Egypt.
}

Received: November 14, 2019

Accepted: December 21, 2019

Online Published: February 20, 2020

doi:10.5539/ies.v13n3p90

URL: https://doi.org/10.5539/ies.v13n3p90

\begin{abstract}
Though there is an existence of writings on human capital and its relationship to growth, but it has missed the economic impact of universities. It is known that the knowledge of economy has a positive role in achieving economic development. So my paper focuses on the role of education expenditure in achieving economic development. The human resource is the basis for growth and development because it is able to achieve the appropriate scientific achievement and its future economic performance which is a positive return. The improvement in performance of skilled workers will be affected if Saudi government increases the education expenditure in addition to the investment in human capital. From here we can say that the human resources and the universities (government education expenditure) are two sides of a single coin whose basic and sole objective is economic growth. Therefore, this paper will test the relationship between education expenditure and economic development during the period from 2003 to 2019 through a theoretical analysis of the relationship of higher education to economic development. To explore the relationship between spending on education and economic development the author used econometric technique to analyze the study by using multi regression model depending on weighted least square (WLS). The study results show that there is a significant relationship between Saudi education expenditure and economic development, but regarding to R \& D expenditure it is not significant. So the author excluded it from the model due to lack of data. Furthermore, the model WLS is effective to explore results and relations between dependent and independent variable in the case of Saudi Arabia.
\end{abstract}

Keywords: education expenditure, university, scientific research, WLS

\section{Introduction}

There is no doubt that development is a necessary requirement for all societies, as the various developed and developing countries depend on same approach, and this will only be achieved through the role of educational institutions. Therefore, universities have an effective role in promoting societies to achieve sustainable development through relying on scientific research and its various applications to create a kind of social and economic progress.

This is in addition to the increasing role of educational institutions in general and the universities in particular through the expertise of their professors and their faculties in the continuous improvement of education and simulation of developed countries and continuous training for their students, which will automatically return to the country after the graduation of their students and their training in the labor market.

It is possible to point out that education in general and universities in particular are the main providers of community services due to their impact on the current situation and the good follow-up of the events in which students are transported in a simplified knowledge form, so that they can solve any unexpected problems through their ideas that generate and flourish modern societies.

Hence, we can explain the importance of the study which indicates the importance of the role of universities (higher educational institutions) in achieving the desired development in the light of the 2030 vision of Saudi Arabia.

The first message to Muslims was to search for and manage the knowledge since the first day of Islam, which clearly demonstrates the importance of science and knowledge in Islamic religion. Although the search for 
knowledge is an instinct in mankind, Islam has raised this instinct and direction to develop this mankind and enable him to make maximum benefit of the natural resources in the earth and its blessings; even it makes seeking knowledge obligatory for all Muslims.

Education is one of the most important elements of development. There is no doubt that a country will not be able to achieve sustainable development without investment in human resources. Education helps people to raise awareness, understand their abilities and understand the world around them. Education also contributes to improving the quality of people's lives, promotes and encourages entrepreneurship and technological progress through research and development. In addition, education plays an important role in securing economic and social progress and improving income distribution, which is a fundamental human right.

So it can be referred to Saudi Arabia which has put the education sector at first and has been interested in spending on education and scientific research because of its importance in achieving developmental returns.

Education is a major locomotive in reaching sustainable development. The education sector has recently achieved rapid development, including infrastructure and spending, however, it is still below expectations.

So my article puts a fundamental question represented as would Saudi universities have a clear contribution to economic development?

Therefore, the role of universities should be given utmost importance and considered as one of the institutions that contribute to the advancement of society through these objectives

It is scientifically known that the internal variables of any society or country affect positively or negatively, the development and continuous improvement. Therefore, the objectives of the study are determined as follow.

1) To examine the relationship between education expenditure and economic development.

2) To empirically test the effect of independent variables on GDP especially in future.

In order to achieve the desired objectives the author first analyzed the existing situation in Saudi Arabia in order to reach to what we are pursuing and identify the challenges that the Kingdom of Saudi Arabia will face in reaching the development vision.

\section{Literature Review}

There are many people who believe that the university has the primary objective of spreading science. The main goal of universities is not only to disseminate the knowledge of science and learning but also extend their influence outside their environment to contribute to solving many social problems.

Specialized Councils (1998) showed that the universities have an important societal role represented in their service centers and what they offer to their students, faculty members or any individual outside the university organization to create comprehensive community development.

Goldin and Katz (2007), and Schofer and Meyer (2005) explained the importance of human capital and its relation to development. Social and economic progress is due to the human capital, and its increase will have a positive impact on GDP (Gennaioli et al., 2013).

In the area of innovation, universities have a prominent role to play by increasing reliance on innovations that increase the productivity of companies. The development of companies will be positively affected by the role of universities in influencing innovative and sophisticated products (Noel \& Schankerman, 2013).

Also Harmon, Oosterbeek, and Walker (2003) explained that the more educated countries grow faster because of enabling the workforce to create new technologies and use all technology in local production. Barro and Sala-i-Martin (2000) highlighted the need to invest in the human capital that generates growth and increases capital.

Over the course of time that spending on education in any country will have an economic impact locally and regionally. This will be seen from the expansion of higher education that will drive economic growth (Aghion et al., 2009; Kantor \& Whalley, 2014).

There are many recent studies and theories that have linked the impact of education to economic development. It described the educational system and its relation to economic growth in the integrated economic entity. Agasisti (2010) stresses in his / her paper the need for more resources to reach future development.

According to the improvement of the quality of graduates and the quality of manpower and the impact of education on productivity, Lange and Topel (2006), and Benhabib and Spiegel (1994) differed that education is the key element of increasing productivity within the economy for its ability to participate in many local and regional 
decisions.

And the contribution of human capital is one of the factors that have an active role in achieving economic development. Sianesi and Reenen (2003) found that countries that have allocated their resources inappropriately have not benefited from investments in human capital in terms of economic growth.

Moreover, many studies have dealt directly with the role of universities and economic performance. Universities in the 14th century in Germany were the cause of the trade and industrial revolution as Cantoni and Yuchtman (2013).

Thomas et al. (2012) described successful academic development for teachers will be the first step for educational sustainability but many researchers have argued that education and development extended to include providing academics with modern teaching methods as Macdonald and Wisdom (2002), and Hegarty (2008).

On the other side, several studies have dealt directly with the role of universities and economic performance represented in the role of innovations which is made by universities' students and which contributes to economic growth in various US provinces (Hausman, 2012).

Classical thought has shown that education is an intrinsic social value in various fields. It is not linked to the economy but between 1776 and 1848, specifically in Europe, education was no longer isolated from economic. Social, political, intellectual and professional activities have become a return to quality education while Bauchet and Kuznets (1969) noted that economic growth is related to the institutional and intellectual adjustments that it requires.

Aghion, David, and Foray (2009) showed the importance of "systems-theoretic" approaches which related to dynamics of science, technology and innovation which achieve economic growth through neo-Schumpeterian or when attract more R\&D.

The greatest evidence of the importance of higher education and its effective relationship with economic development is the State of Korea, which has been able to raise the rates of education from 16\% in 1980 to $39 \%$ in 1990 and continues to rise to $68 \%$ in 1996 as a result of their good allocation of resources to education in all its stages (Birdsall \& Page, 1993).

\section{Methodology}

Regarding to the objectives of the study on the possibility of a relationship between spending on education and economic development of Saudi Arabia according to 2030 Vision

In order to test the objectives of the study has been determined the nature of the variables to study the moral spending on education and scientific research as well. Moreover, there is a need for studying the impact of spending on education to achieve economic growth rates, besides its impact on the level of per capita income growth.

$$
\begin{array}{ll}
\mathrm{Y}: \mathrm{GDP} & \mathrm{X}_{3} \text { : Exports } \\
\mathrm{X}_{1} \text { : GDP per capita } & \mathrm{X}_{4} \text { : Research and development } \\
\mathrm{X}_{2} \text { : Education Expenditure } & \\
\text { 3.1 Empirical Study } &
\end{array}
$$

\subsection{Empirical Study}

The following tables show the empirical results of using WLS Model, where the author exchanges Ordinary Least Square Model because the model is not subject to normal distribution. As a result R\&D was excluded because of its inefficiency and not significant impact on economic growth, due to the low percentage allocated by the budget of universities compared to the proportion of total spending on education.

Table 1. Variables

\begin{tabular}{cccc}
\hline Model & Variables Entered & Variables Removed & Method \\
\hline 1 & per capita, education expenditure, exports ${ }^{\mathrm{a}}$ & Research and development. & Enter \\
\hline
\end{tabular}

a. All requested variables entered; b. Dependent Variable: GDP 
Table 2. Model summary

\begin{tabular}{cccccc}
\hline Model & R & R Square & Adjusted R Square & Std. Error of the Estimate & Durbin-Watson \\
\hline 1 & $.975 \mathrm{a}$ & .951 & .941 & 1.73315 & 1.533 \\
\hline
\end{tabular}

Note. Predictors: (Constant), per capita, education expenditure, exports and Table 2 refer to the vector error correlation model.

Table 3. Anova

\begin{tabular}{ccccc}
\hline Model & Sum of Squares & Df & Mean Square & F \\
Regression & 878.262 & 3 & 292.754 & 97.461 \\
Residual & 45.057 & 15 & 3.004 & $.000^{\text {a }}$ \\
Total & 923.319 & 18 & & \\
\hline
\end{tabular}

Note. a. Predictors: (Constant), per capita, education expenditure, exports; b. Dependent Variable: GDP; Weighted

Least Squares Regression-Weighted by weight

\section{Result}

Where the coefficient of determination contributes to know how much education expenditure achieves economic development. It has reached to $95 \%$.

On other hand, $\mathrm{R}^{2}$ results show $97 \%$ and adjusted $\mathrm{R}^{2}$ is closed to $94 \%$ this is an indication that the entire model is important to clarify the causal relationship between all the variables, whether an independent or dependent variable as it is shown in Table 2.

Also results of Anova table are shown in Table 3 that reflect to that the model is significant and Durbin-Watson reflects that there is no auto correlation. Table 4 below determines all parameters are statistically significant plus that multi regression is significant where any change in $X_{1}$ only one unit this will lead to change in dependent variable.

It can be noted that $\mathrm{x}_{1}, \mathrm{x}_{2}, \mathrm{x}_{3}$ (education expenditure,exports, and GDP per capita) are able to affect in the dependent variable. Therefore, the analysis examined the possibility of existence relationship between education and economic. This can be determined by the following equation.

$\mathrm{Y}=\mathrm{b} 0+\mathrm{b} 1 \mathrm{x} 1+\mathrm{b} 2 \times 2+\mathrm{b} 3 \mathrm{X} 3+\mathrm{u}$

GDP $=167.520-24.244 \mathrm{x}_{1}+.194 \mathrm{x}_{2}+.859 \mathrm{x}_{3}+\mathrm{u}$

Table 4. Coefficients

\begin{tabular}{|c|c|c|c|c|c|c|}
\hline & \multirow{2}{*}{ Model } & \multicolumn{2}{|c|}{ Unstandardized Coefficients } & \multirow{2}{*}{$\frac{\text { Standardized Coefficients }}{\text { Beta }}$} & \multirow{2}{*}{$\mathrm{t}$} & \multirow{2}{*}{ Sig. } \\
\hline & & $\mathrm{B}$ & Std. Error & & & \\
\hline \multirow{4}{*}{1} & (Constant) & 167.520 & 41.633 & & 4.024 & .001 \\
\hline & education expenditure & -24.244 & 5.938 & -.892 & -4.083 & .001 \\
\hline & exports & .194 & .083 & .514 & 2.341 & .033 \\
\hline & per capita & .859 & .193 & 1.304 & 4.447 & .000 \\
\hline
\end{tabular}

Note. a. Dependent Variable: GDP; b. Weighted Least Squares Regression-Weighted by weight

\section{Discussion}

The development of any association in any country is related to the extent of its culture and the level of scientific research. This made us examine the relationship between education and the role of universities and their constructive role in development.

There is a close relationship between education and economic development; where human are the most important aspect. Economic development requires skilled and trained labor this can only be achieved through education. Economic development is responsible for providing capital for education.

\subsection{The impact of Higher Education on the Economy}

Economists have never been aware of the role of education. In the theories of human capital and the role of higher education (Becker \& Lewis, 1992), and there are theories of internal growth given by Lucas (1988), Romer (1990), 
and Rebelo (1991). These studies, which showed a link between economic growth and increase in the level of human capital, highlighted the role of education in development.

Because the human is one of the most important factors that contribute to the development through increase the productivity of the individual. Definitely, this is so difficult to happen without education.

Several theories of economic growth have been made clear that education, training and development play an important role in achieving high economic growth rates and consider one of the most important sources of sustainable development. There are some studies that indicated a relationship between education and income as Psacharopoulos (1994) pointed out to any increase in the workforce is affected by the level of education, where income differs from high level of education to medium with increase from $40 \%$ to $60 \%$.

What is certain regionally and globally is that different wages of workers are due to education. People have Higher education degree earn more than those without a university degree.

\subsection{Education, Productivity, and Economic Growth}

Education has a positive role in increasing productivity because the quality of education will play a major role in increasing the productivity of different sectors by educated and trained workers on different skills who will be innovative and creative and will directly add to the domestic product of the state.

As for the relationship of education to economic growth, World Bank studies by Birdsall and Page (1993) indicated that education is profitable for investment. Korea is considered a good example of the importance of education, which has been able to raise education rates as a result of the allocation of resources. Moreover when we focus on the relationship between the role human and physical capital to reduce poverty and achieve development where Shabbir (1990), agreed that without the basis of macroeconomic stability and the development of human capital, development would not have been achieved.

Recently, investing in human capital through the increase of the level of education will have a sustainable development role as Birdsall and Page (1993) stated. Jamison and Moock (1984) reached to the conclusion that education has a positive impact on increasing productivity of agricultural crops. Where educated farmers are able to use the latest technology and positively affect productivity.

This is in addition to the different growth theories, which focused on the need for learning and research to increase productivity as confirmed by Lucas (1988) and Perotti (1993), that education has the primary role of increasing productivity, increasing innovation and growth of exports, which contribute to increasing economic growth rates.

\subsection{The Role of Higher Education in Human Development and the Labor Market}

Higher education and its institutions, represented in public and private universities, have a role in achieving a balance in the labor market and developing it to advance development because it is considered a base of movement, social change and excellence to meet the challenges of the times.

The human resource is the key to economic progress and the basis of different wealth formation where the human resource is the most important goal of the national transformation of the state. Since economic development is based on the possibility of creating a workforce with diverse skills, which will have a positive impact on increasing the interest in manufacturing.

If we can point out that education is an industry of the human resource and investing in the human is certainly the way to the rise of nations, therefore, universities must work on sustaining the community with effective human in all fields. Universities are the primary factor driving societies to development through its graduation to different cadres positively affect the labor market to develop future development to meet the challenges of competition and globalization.

Universities have a fundamental role in creating a job market capable of absorbing graduates. In engineering colleges, for example, students must be actively integrated into industrial disciplines and put them in an industrial environment to solve problems and training during the theoretical study.

This always requires the university to develop plans for student education and the formation of practical knowledge along with theoretical knowledge. In this way, we believe that we can create distinguished graduates who can compete and innovate, rather than graduating a generation that is unable to develop and join unemployment after graduation.

Moreover, the role of positive universities in the development of research works and achieves more benefit to human and society together. 


\section{A Proposed Vision for the Role of Saudi Universities in Achieving Sustainable Development}

In light of the changes witnessed by countries in the era of science and automation as well as our interaction with the outside world, especially in the presence of globalization, and this will not be possible only, the need to integrate universities in community services and this should be concerned by current governments and give prioritize this.

Therefore, it is necessary to adopt a perception based on previous studies of others, and the need to give an active and constructive role to Saudi universities in implementing the vision targeted by the state by 2030 .

I strongly believe that the university plays a fundamental role in addressing pre-university education issues. The pre-university education in the Kingdom of Saudi Arabia is not entirely appropriate with physical potential.

It is necessary to make possible adjustments in teaching methods in the basic stages, and provide the student with knowledge which makes him think and create instead of the policy of memorization.

Our vision is based on three main pillars, where the state's authorities can benefit from it. These pillars include education, scientific research and finally the service of society through the adoption of many strategies and plans that contribute to the building and development of the state and to identify any emergency problems with the possibility of providing solutions. I believe that the sustainable economic development in this case will be a function of three variables and we can represent them as follows: $D=F n(E, R, S)$

Where: D target Development, E: Knowledge Education, R: research and S: Community Service.

This function has positive relationship to the interest in continuing education, research publication and the provision of community service. Integrating these factors will develop the country for the best and the possibility of achieving sustainable future development. These factors represented as below.

\subsection{Towards a Knowledgeable Society}

The 20th century has witnessed a great development in the field of knowledge if compared to previous periods. It has a developmental impact. Moreover, development depends on the value of knowledge beside factors of production.

\subsubsection{Elements of Activating Education Include}

a) To identify the problems of pre-university education and try to develop it and submitting best policies.

b) Rely on international mother's books during the educational process so as not to overlook the student basic concepts.

c) Reliance on modern methods of education and be away from filling in curriculum.

d) Link theoretical education to practical reality, train students in preparation for their integration into the labor market.

\subsubsection{R\&D (Scientific Research)}

In the developed countries, the universities submit special research and development programs by providing the appropriate scientific environment in which scientific research could grow. These institutions provide the necessary funds for the provision of laboratory equipment and scientific equipment needed by researchers in their various disciplines.

Without scientific research, the university will only become a school of science and knowledge produced by others not a center of scientific creation and innovation. So there is a need to take care of scientific research to solve the various problems facing society.

Scientific research which is carried out by universities and institutions of higher education has an essential role in any country that seeks development and progress to identify the capabilities of scientific and technical universities. Scientific research always handles issues and problems, so it is necessary for the universities to provide the suitable support and consistently. Thus that will be a race to reduce the problems, find solutions, and alternatives to the issues of society with the utmost impartiality.

Moreover, scientific research has a very important role in achieving development and must be relied on the circumstances that concern with the need to create non-oil sources and revenues to increase the economic growth of the Kingdom of Saudi Arabia and this is through:

a) Conducting applied research for government institutions to deal with the problems facing the society.

b) Helping the various category of society by providing ideas to manage their small projects. 
c) Direct scientific research to solve and develop society's problems.

d) Search for renewable sources instead of relying permanently on oil revenues.

e) To create a research unit, whose primary role is to research deeply the problems and study them and to identify the conclusions and recommendations for making the necessary decisions.

The following figure illustrates the interrelationship between scientific research and universities to reach the desired development.

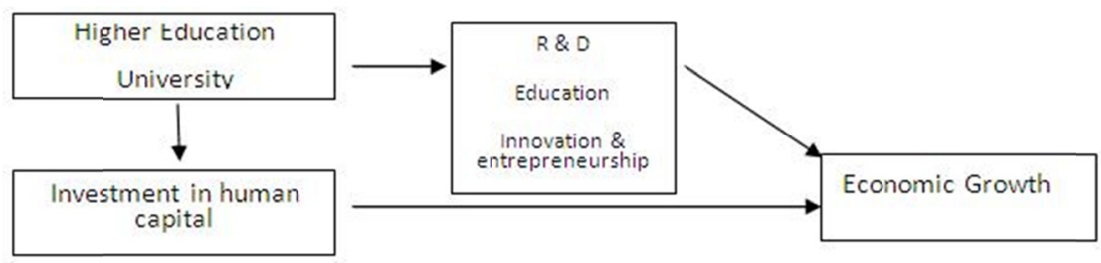

Figure 1. Scientific research and universities the way to economic growth

\subsubsection{Community Service}

There are many areas of community development offered by universities to their communities according to the different problems of society and the ability of universities to settle these problems.

Community service is one of the most important elements that will benefit the state, and because it is the main objective of the university to achieve, where interest in society makes universities the basis for the economic renaissance of countries.

Therefore, the State must consult with universities on a permanent basis and on the development of plans to be adopted by governments.

Universities contribute to community service by linking applied research with the needs of different sectors of productivity or service as well as cooperating with the institutions in the study and solve the problems they face. Integration between universities and all agricultural, industrial and commercial sectors will transfer obstacles or problems to the universities to re-study and provide solutions.

It is beyond doubt that the development of societies needs to integrate universities and not isolating them from society where an educated individual is the foundation of the renaissance of society, so any increase in government spending on universities is considered as an investment in human resources development.

\section{Challenges Facing Universities in Achieving Sustainable Development}

Although there is a proposed perception to achieve the desired development through Integration of higher educational institutions, but there are still challenges to development and scientific research to achieve its results for instances:

\section{First: Government Budget}

Based on the government budgeting and the lack of joint cooperation of the beneficiaries in financing these activities, many studies have shown that there is a positive relationship between spending on scientific research and technological development. So from my point of view there is an urgent need to apply the results of empirical research to achieve sustainable development in various research fields. Thus, universities will have an active role in the development of society and the involvement of beneficiaries in the implementation of results.

\section{Second: Implementation Methods}

The implementation of research projects carried out by researchers faces many problems; therefore it is necessary to collect the data of researches and studies carried out to know its economic importance and the possibility of implementation so that it can be marketed to the authorities.

This can be summarized through the scientific knowledge produced by universities which need centers that support these ideas to produce and manufacture for the benefit of society.

\section{Conclusion}

There is no doubt that the University has a prominent role in identifying the problems facing society. The success 
of countries and societies depend on the success and development of universities and its openness to educational institutions as investment in the human resource in the fields of education and training is considered the first goal of the advancement of the societies in various developed or developing countries. Continuous improvement and permanent development of individuals is a complex task to obtain:

- Educational systems conform to the quality standards adopted by countries and provide pioneer opportunities for graduates in the labor market to achieve the economic growth of his country.

- Providing certificates that can compete with other educational universities anywhere.

Moreover education is the important foundation for every step towards formation comprehensive development, especially human development. It is focusing on the human being as the most important resource in the development process. In order to raise the level of education, it is necessary to increase spending on the education sector to meet the demand for educational services in the coming years.

Universities are the foundation in the process of creating and developing economic expertise through entrepreneurs and innovate. Universities are a contributor to society's efforts to achieve sustainable development through its neutral role in building minds and making ideas capable of solving problems to enhance the welfare of economic and social development in a way that adds and develops society.

Last but not least, Saudi universities have an important role in creating the right conditions for the individual and the institutions working in the community together to take advantage of physical and human possibilities as a mirror that reflects the negative and positive of society.

\section{Recommendation}

In our belief in the role of universities and their effective role in community development, we believe that:

- There is a necessity to determine the objectives of universities and a clear vision for the future of their students to ensure sustainable development.

- The need to simulate society with universities' involvement in the practical market.

- Building a competitive generation in the labor market in various fields as a basic goal for the renaissance of the state.

- Universities should adopt a development environment that handle various cultural, social and economic fields

- Universities have a primary burden of creating a workforce that has the ability to be familiar in different economic conditions

Emphasize the importance of improving the level of education and connect between education and its various approaches on the one hand and the requirements of development in society.

The university has a key role to prepare human resource that has capability of change which will positively affect the development of the labor market and thus achieve sustainable development and this will come through:

Continuous participation in scientific conferences to transfer different international experiences.

The need to spread knowledge and education among the members of the community.

The inevitability of raising the expenditure on scientific research.

- Reviewing the sources of financing scientific research activities and recommending the participation of the producing companies or the beneficiaries of the results of the scientific research

Interest in spending on scientific research activities in the industrial sector as one of the productive sectors.

If universities have a role in the rise of societies with its human resources, scientific research and scientific knowledge, Therefore, from my point of view there is need to review the outputs of the universities and obligate them to follow up the performance of the state in many important sectors of industrial, commercial, tourism, etc., which will lead to sustainable development.

Last but not least decision makers in Saudi Arabia must increase the allocated balance to R and D for its importance in improving economic performance. This is what makes me agree with Jones and Williams (2000), and Gerybadze et al. (2010), in reliance research and development will serve economic development if invested well.

\section{References}

Agasisti, T. (2010). Stratification in higher education: A comparative study. 
https://doi.org/10.1080/09645292.2010.488410

Aghion, P., Blundell, R., Griffith, R., Howitt, P., \& Prantl, S. (2009). The effects of entry on incumbent innovation and productivity. The Review of Economics and Statistics, 91(1), 20-32. https://doi.org/10.1162/rest.91.1.20

Aghion, P., David, P. A., \& Foray, D. (2009). Science, technology and innovation for economic growth: linking policy research and practice in 'STIG Systems'. Research policy, 38(4), 681-693. https://doi.org/10.1016/j.respol.2009.01.016

Barro, R. J., \& Sala-i-Martin, X. I. (2000). Economic Growth (The MIT Press) (2nd ed.). Retrieved from https://www.amazon.com/Economic-Growth-Press-Robert-Barro/dp/0262025531

Bauchet, P., \& Kuznets, S. (1969). Modern Economic Growth, Sciences Po University Press. Journal Revue économique, 20(1). https://doi.org/10.2307/3500402

Becker, W. E., \& Lewis, D. R. (1992). Preview of the Economics of American Higher Education. In The Economics of American Higher Education (pp. 1-13). Springer, Dordrecht. https://doi.org/10.1007/978-94-011-2950-3_1

Benhabib, J., \& Spiegel, M. M. (1994). The role of human capital in economic development evidence from aggregate cross-country data. Journal of Monetary economics, 34(2), 143-173. https://doi.org/10.1016/0304-3932(94)90047-7

Birdsall, N., \& Page, J. (1993). East Asian miracle: Economic growth and public policy. World Bank, Policy Research Department. http://documents.worldbank.org/curated/en/975081468244550798/Main-report

Cantoni, D., \& Yuchtman, N. (2013). The political economy of educational content and development: Lessons from history. Journal of Development Economics, 104, 233-244. https://doi.org/10.1016/j.jdeveco.2013.04.004

Gennaioli, N., La Porta, R., Lopez-de-Silanes, F., \& Shleifer, A. (2013). Human capital and regional development. The Quarterly journal of economics, 128(1), 105-164. https://doi.org/10.1093/qje/qjs050

Gerybadze, A., Hommel, U., Reiners, H. W., \& Thomaschewski, D. (Eds.). (2010). Innovation and international corporate growth. Heidelberg: Springer. https://doi.org/10.1007/978-3-642-10823-5

Goldin, C., \& Katz, L. F. (2007). The race between education and technology: The evolution of US educational wage differentials, 1890 to 2005 (No. w12984). National Bureau of Economic Research. https://doi.org/10.3386/w12984

Harmon, C., Oosterbeek, H., \& Walker, I. (2003). The returns to education: Microeconomics. Journal of economic surveys, 17(2), 115-156. https://doi.org/10.1111/1467-6419.00191

Hausman, N. (2012). University innovation, local economic growth, and entrepreneurship. US Census Bureau Center for Economic Studies Paper No. CES-WP-12-10. https://doi.org/10.2139/ssrn.2097842

Hegarty, K. (2008). Shaping the self to sustain the other: Mapping impacts of academic identity in education for sustainability. Environmental Education Research, 14(6), 681-692. https://doi.org/10.1080/13504620802464858

Jamison, D. T., \& Moock, P. R. (1984). Farmer education and farm efficiency in Nepal: The role of schooling, extension services, and cognitive skills. World Development, 12(1), 67-86. https://doi.org/10.1016/0305-750x(84)90036-6

Jones, C. I., \& Williams, J. C. (2000). Too much of a good thing? The economics of investment in R\&D. Journal of economic growth, 5(1), 65-85. https://doi.org/10.1023/A:1009826304308

Kantor, S., \& Whalley, A. (2014). Knowledge spillovers from research universities: evidence from endowment value shocks. Review of Economics and Statistics, 96(1), 171-188. https://doi.org/10.1162/REST_a_00357

Lange, F., \& Topel, R. (2006). The social value of education and human capital. Handbook of the Economics of Education, 1, 459-509. https://doi.org/10.1016/S1574-0692(06)01008-7

Lucas Jr., R. E. (1988). On the mechanics of economic development. Journal of monetary economics, 22, 3-42, https://doi.org/10.1016/0304-3932(88)90168-7

Macdonald, R., \& Wisdom, J. (2003). Academic and educational development: Research, evaluation and changing practice in higher education. Routledge. https://doi.org/10.4324/9780203417041 
Noel, M., \& Schankerman, M. (2013). Strategic patenting and software innovation. The Journal of Industrial Economics, 61(3), 481-520. https://doi.org/10.1111/joie.12024

Perotti, R. (1993). Political equilibrium, income distribution, and growth. The Review of Economic Studies, 60(4), 755-776. https://doi.org/10.2307/2298098

Psacharopoulos, G. (1994). Returns to investment in education: A global update. World development, 22(9), 1325-1343. https://doi.org/10.1016/0305-750x(94)90007-8

Rebelo, S. (1991). Long-run policy analysis and long-run growth. Journal of political Economy, 99(3), 500-521. https://doi.org/10.1086/261764

Romer, P. M. (1990). Human Capital and Growth: Theory and Evidence. Carnegie-Rochester Conference Series on Public Policy. Spring 1990b, 32, 251-286. https://doi.org/10.1016/0167-2231(90)90028-J

Schofer, E., \& Meyer, J. W. (2005). The worldwide expansion of higher education in the twentieth century. American sociological review, 70(6), 898-920. https://doi.org/10.1177/000312240507000602

Shabbir, T. (1990). Human Resource Development? Review of Issues and Evidence. https://doi.org/10.30541/v29i3-4pp.345-349

Sianesi, B., \& Reenen, J. V. (2003). The returns to education: Macroeconomics. Journal of economic surveys, 17(2), 157-200. https://doi.org/10.1111/1467-6419.00192

Specialized Councils. (1998). Maximizing the returns of higher and university education outcomes in contemporary society. Unpublished research papers.

Thomas, I., Hegarty, K., \& Holdsworth, S. (2012). The education for sustainability jig-saw puzzle:

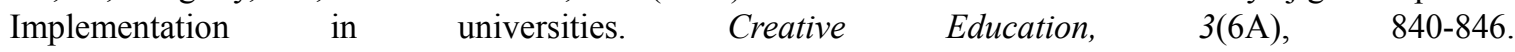
https://doi.org/10.4236/ce.2012.326125

\section{Copyrights}

Copyright for this article is retained by the author(s), with first publication rights granted to the journal.

This is an open-access article distributed under the terms and conditions of the Creative Commons Attribution license (http://creativecommons.org/licenses/by/4.0/). 